\title{
The Challenge of the Biochemical Control of Acromegaly
}

\author{
Alessandro Ciresi* and Carla Giordano \\ Biomedical Department of Internal and Specialist Medicine (DIBIMIS), University of Palermo, Italy
}

Submission: August 18, 2017; Published: November 15, 2017

*Corresponding author: Alessandro Ciresi, Section of Endocrinology, Diabetology and Metabolic Diseases, Biomedical Department of Internal and Specialist Medicine (DIBIMIS), University of Palermo, Piazza delleCliniche 2, 90127 Palermo, Italy, Tel: 916552709; Email: a.ciresi@virgilio.it

\section{Opinion}

Acromegaly is a rare andslowly progressive disease characterized by an excessive growth hormone (GH) secretion and increased circulating levels of insulin-like growth factor 1 (IGF-1), more frequently caused by a pituitary adenoma [1,2]. Unfortunately, its diagnosis is often delayed of about 5 years due to the insidious nature of the disease $[3,4]$ and, consequently, acromegalic patients often show overt systemic complications and comorbidities at diagnosis, with a decreased life expectancy [5-7]. The most common complications of acromegaly, including cardiovascular, metabolic andrespiratoryalterations, have been demonstrated to be closely related to GH levels [8]. Therefore, the achievement of optimal biochemical control of acromegaly is crucial and it has been shown to be correlated with improvement of clinical signs and symptoms, comorbidities and mortality risk $[9,10]$. A "safe" GH or IGF-1 level should be the level of hormone below which the increased mortality associated with acromegaly is reduced to that seen in the general population.

During the years various guidelines and consensus statements provided algorithms to clarify the interpretation of GH and IGF-1 levels during the management of acromegaly, also differentiating them according to the treatment, and the criteria of cure have changed over time. From the first official criteria defined in 2000 [11], many advances have been made in the subsequent years. Random GH does not always provide a reliable measure of disease activity, because of overlaps between the upper range of normal GH levels of healthy subjects and levels of acromegalic patients [12]. To date, the current GH nadir limits after OGTT seem to be adequate to define remission of acromegaly [13]. If after pituitary surgery the GH nadir after OGTT of less than $1 \mu \mathrm{g} / \mathrm{l}(0.4 \mu \mathrm{g} / \mathrm{l}$ with ultrasensitive assays) with a concomitant normalization of IGF1, defines control of acromegaly, on the other hand the GH suppression during OGTT is of limited value in evaluating biochemical control in patients who are receiving pharmacological treatment. In these cases, IGF-1 and a random $\mathrm{GH}<1 \mu \mathrm{g} / \mathrm{l}$ are sufficient for assessment of biochemical response, with the exception of patients treated with pegvisomant, in whom IGF-1 becomes the main and reliable biochemical marker of therapeutic efficacy $[14,15]$. However, despite the advances in acromegaly management and treatment, some aspect of the biochemical control remain a challenge, because of the availability of standardized assays, the difficult comparison of hormonal levels measured by traditional vs. modern GH assays or the discrepant hormonal results in a fair number of patients. In addition, the GH levels adopted as criteria for biochemical control of acromegaly must be considered not only assay, but also gender, age, and BMI specific, indicating the need of individual cutoff limits for each assay and in groups of subjects with homogeneous gender, age and BMI. Indeed, to date, these factors are not considered for the interpretation of the GH levels, although this point could represent a limit in the interpretation of many results $[11,16]$. In this light, IGF-1 represents a more reliable marker of disease activity because of the availability of gender-, age- and assay-normalized values [17].

Generally, in cases of discrepant values of GH and IGF1 is mandatory to require biochemical confirmation with an expectant approach before starting additional treatment or increasing the dose of actual treatment after excluding all possible interfering causes and in these cases a closely follow-up is needed [18].

A challenge also remains the question on the optimal frequency of hormonal measurementsduring the follow-up. Due to the different half-lives of GH and IGF-1 and the rate of discordant hormonal levels, it is important to define the appropriate and optimal timing intervals to assess the biochemical evaluation for each treatment. To date, the biochemical evaluation after 12 weeks from surgery seems to be a reliable marker of remission $[11,13]$, while the biochemical effectiveness of medical treatment should be assessed initially at 3-6 months intervals [19], although the optimal frequency of follow-up measurements remain to 
be clarified. However, finding new biochemical markers could certainly help to guide treatment decision when discordant hormonal levels are obtained.

\section{References}

1. Ben-SA, Melmed S (2008) Acromegaly. Endocrinol Metab Clin North Am 37(1): 101-122.

2. Melmed S (2009) Acromegaly pathogenesis and treatment. J Clin Invest 119(11): 3189-3202.

3. Chanson P, Salenave S (2008) Acromegaly. Orphanet J Rare Dis 3: 17.

4. Reid TJ, Post KD, Bruce JN, Nabi KM, Reyes VCM, et al. (2010) Features at diagnosis of 324 patients with acromegaly did not change from 1981 to 2006: acromegaly remains under-recognized and under-diagnosed. Clin Endocrinol (Oxf) 72(2): 203-208.

5. Colao A, Ferone D, Marzullo P, Lombardi G (2004) Systemic complications of acromegaly: epidemiology, pathogenesis, and management. Endocr Rev 25(1): 102-152.

6. Pivonello R, Auriemma RS, Grasso LF, Pivonello C, Simeoli C, et al. (2017) Complications of acromegaly: cardiovascular, respiratory and metabolic comorbidities. Pituitary 20(1): 46-62.

7. Sherlock M, Ayuk J, Tomlinson JW, Toogood AA, Aragon AA, et al. (2010) Mortality in patients with pituitary disease. Endocr Rev 31(3): 301-342.

8. Mercado M, Gonzalez B, Vargas G, Ramirez C, de los Monteros AL, et al. (2014) Successful mortality reduction and control of comorbidities in patients with acromegaly followed at a highly specialized multidisciplinary clinic. J Clin Endocrinol Metab 99(12): 4438-4446.

9. Ben SA, Sheppard MC, Stephens JM, Pulgar S, Melmed S (2011) Clinical, quality of life, and economic value of acromegaly disease control. Pituitary 14(3): 284-294.

10. Holdaway IM, Bolland MJ, Gamble GD (2008) A meta-analysis of the effect of lowering serum levels of GH and IGF-I on mortality in acromegaly. Eur J Endocrinol 159(2): 89-95.

11. Giustina A, Barkan A, Casanueva FF, Cavagnini F, Frohman L, et al. (2000) Criteria for cure of acromegaly: a consensus statement. J Clin Endocrinol Metab 85(2): 526-529.

12. Freda PU, Post KD, Powell JS, Wardlaw SL (1998) Evaluation of disease status with sensitive measures of growth hormone secretion in 60 postoperative patients with acromegaly. J Clin Endocrinol Metab 83(11): 3808-3816.

13. Katznelson L, Laws ER, Melmed S, Molitch ME, Murad MH, et al. (2014) Endocrine Society. Acromegaly: an endocrine society clinical practice guideline. J Clin Endocrinol Metab 99(11): 3933-3951.

14. Trainer PJ, Drake WM, Katznelson L, Freda PU, Herman BV, et al. (2000) Treatment of acromegaly with the growth hormone-receptor antagonist pegvisomant. N Engl J Med 342(16): 1171-1177.

15. Giustina A, Chanson P, Bronstein MD, Klibanski A, Lamberts S, et al. (2010) Acromegaly Consensus Group. A consensus on criteria for cure of acromegaly. J Clin Endocrinol Metab 95(7): 3141-3148.

16. Colao A, Lombardi G (2008) Should we still use glucose-suppressed growth hormone levels for the evaluation of acromegaly? J Clin Endocrinol Metab 93(4): 1181-1182.

17. Clemmons DR, Van Wyk JJ, Ridgway EC, Kliman B, Kjellberg RN, et al. (1979) Evaluation of acromegaly by radioimmunoassay of somatomedin-C. N Engl J Med 301(21): 1138-1142.

18. Kanakis GA, Chrisoulidou A, Bargiota A, Efstathiadou ZA, Papanastasiou $\mathrm{L}$, et al. (2016) The ongoing challenge of discrepant growth hormone and insulin-like growth factor I results in the evaluation of treated acromegalic patients: a systematic review and meta-analysis. Clin Endocrinol (Oxf) 85(5): 681-688.

19. Melmed S, Casanueva F, Cavagnini F, Chanson P, Frohman LA, et al. (2005) Consensus statement: medical management of acromegaly. Eur J Endocrinol 153(6): 737-740.

\section{Your next submission with Juniper Publishers} will reach you the below assets

- Quality Editorial service

- Swift Peer Review

- Reprints availability

- E-prints Service

- Manuscript Podcast for convenient understanding

- Global attainment for your research

- Manuscript accessibility in different formats ( Pdf, E-pub, Full Text, Audio)

- Unceasing customer service

Track the below URL for one-step submission https://juniperpublishers.com/online-submission.php 